\title{
SCHOOL BASED MANAGEMENT (SBM) TO IMPROVE QUALITY OF EDUCATION IN KHM NUR JUNIOR HIGH SCHOOL SURABAYA
}

\author{
Ulfa Suhroh \\ Ulfah_2018@gmail.com
}

\begin{abstract}
Currently, education management in Indonesia recognizes two mechanisms, namely centralization and decentralization system, in the centralized system of education administration regulated by the central government. This study aims to find out how the implementation of School Based Management (SBM) in KHM NUR Junior High School Surabaya, knowing what programs are implemented in KHM NUR Junior high School Surabaya and aims to determine what factors that support and hinder the implementation of School Based Management (SBM) in an effort to improve the quality of education at KHM NUR Junior High School Surabaya. The type of research used in this study is Field Research, which is studying intensively about the background of the present state, in the interaction of a social, individual, group, institution, and society. Technique of data analysis used qualitative descriptive. The findings of this study can be concluded; first: Implementation of School Based Management (SBM) at KHM. NUR Junior High School Surabaya has been well scheduled. Second: The programs that have been implemented as the implementation of School Based Management (SBM) in KHM. NUR Junior High School Surabaya in academic and non-academic field. Third: Supporting and inhibiting factors in the implementation of School Based Management (SBM) in KHM. NUR Junior High School Surabaya among others comes from the intern and extern of the school.
\end{abstract}

Keywords: School Based Management (SBM), Quality of Education.

\section{A. Introduction}

The development of science is determined by the development of the world of education, where the world of education has a very strategic role in determining the direction of advancing the quality of education. This can be felt when an educational institution in conducting education which is really good, then the quality can be seen. In contrast, the educational institutions that carried out education merely will produce the mediocre output.

From year to year one of the problems faced by the world of national education is the low quality of education at each level and educational units especially the level of primary and secondary education. So, naturally it becomes anxiety for educational people about how to repair and improve the quality of education to the higher direction. All efforts have been undertaken such as training and improvement of teacher qualifications, procurement of books and instructional tools, improvement of other educational facilities and infrastructure, and enhancement of school leadership and management. However, the quality of education indicator does not show significant change.

In the Indonesian Law no. 20 year 2003 on the National Education System mentioned that education is the key to progress, the better the quality of education organized by a community/nation, it will be followed by the better the quality of the community. Education is a conscious and planned effort to create an atmosphere of learning and learning process in order to make the students actively develop their potential to have spiritual strength, self-control, 
personality, noble character and skills they needed, nation society and state. ${ }^{1}$

One of the components that often targeted causes the declining quality of education is the curriculum. The impression that appears in the community is that every minister will change the curriculum. Whereas, the previous curriculum has not been socialized evenly, suddenly it replaced with a new curriculum. That is, any educational or learning innovation needs to be equitable and continuous socialization, encompassing not only the personal-practical dimensions, but also the philosophical conceptual bases. $^{2}$

Currently, education management in Indonesia recognizes two mechanisms, namely centralization and decentralization system, in the centralized system of everything which deal with the implementation of education is strictly regulated by the central government. While in decentralization, the regulatory authority is left to the local government. It should be emphasized that the implications of decentralization of education management are greater authority given to districts and municipality to cultivate education in accordance with their potential and local needs.

School Based Management provides greater autonomy to schools. Schools have greater authority and responsibility in managing their schools to be more independent. With their independence, schools are more empowered in developing programs that, of course, are more flexible, schools will be more agile in managing and utilizing school resources

\footnotetext{
${ }^{1}$ Standar Nasional Pendidikan (SNP) dan Undang-undang RI No. 20 tentang Sistem Pendidikan Nasional (Bandung, Fokusmedia, 2005),95
}

optimally. With active participation/involvement of school and community members in the organization of schools, a sense of belonging to schools can be improved.

In this connection, one thought emerges towards the management of education which gives flexibility to the school to organize and implement various policies widely. This thinking in its journey is called as School Based Management (MBS).

School Based Management is a strategy to create an effective and productive school. It is a new paradigm of educational management, which provides widespread autonomy for schools, and community engagement within national education policy frameworks. It is an idea of educational decision making that is placed in the closest position to learning, i.e. school. Empowering schools by providing greater autonomy, in addition to show the government's responsiveness to the demands of society is also a means of improving efficiency, quality and equity of education.

There are two important reasons to be able to implement why SBM is important to be implemented in Indonesia's education management system and implementation.

First, SBM can improve accountability of principals and teachers to learners, parents, and communities. The original mechanism of accountability still has to wait for a written report (if any) from the principal or teachers, then with the implementation of SBM from the beginning what should be reported it can be known earlier. For example, prior to SBM, there are not many

\footnotetext{
${ }^{2}$ Muhaimin, Pengembangan Kurikukum PAI di Sekolah dan Perguruan Tinggi, (Jakarta, PT Raja Grafindo Persada, 2005), 26
} 
stakeholders who know how much the budget is set out in the School Cost and Revenue Budget Plan (RAPBS). However, with the implementation of SBM, at the beginning of the new school year, all of them are aware of the School Cost and Revenue Budget Plan, which should be displayed on the school notice board.

Secondly, SBM provides open access to all stakeholders in providing advice and inputs for the establishment of key school-needed policies. Thus, the aspirations of all stakeholders are highly appreciated to be an important part in the determination of the policy to be taken by the school institution. ${ }^{3}$

Based on the above explanation, the writer considers it necessary to study more deeply about School Based Management (SBM) to Improve Quality of Education in KHM. Nur Junior High School Surabaya "

\section{B. Research Methods}

The type of this research is Field Research. It is used to study intensively about the background of the present state, in the interaction of a social, individual, group, institution, and society. ${ }^{4}$ It is also considered a broad approach in qualitative research.

The approach used in this study is Descriptive - Qualitative approach. Bogdan and Taylor defined "Qualitative Method" as a research procedure that produces descriptive data in the form of written or oral words of observable persons and behaviors. According to them, this approach is

\footnotetext{
${ }^{3}$ Suparlan, Manajemen Berbasis Sekolah dari Teori Sampai dengan Praktik ( Jakarta : Bumi Aksara, 2013),53

${ }^{4}$ Husaini Usman dkk, Metodologi Penelitian sosial (Jakarta: PT. Bumi Aksara, 2006), 5.

${ }^{5}$ Lexy J. Moleong, Metode Penelitian Kualitatif : Edisi Revisi (Bandung: PT. Remaja Rosdakarya 2006), 4.
}

directed to the background and the individual holistically. Thus, in this case it should not isolate individuals or organizations into variables or hypotheses, but it need to view them as part of comprehensiveness. ${ }^{5}$

The type of data in this study is divided into two; first primary data source, i.e. data are directly collected by researchers from the first source. ${ }^{6}$ In this research is the principal of KHM NUR Junior High School Surabaya. Second, secondary data sources, i.e. data are collected by the researcher as a supporter of the first source. ${ }^{7}$ This data is in the form of school documents such as school geography, school profiles, school work programs and so forth.

The data sources of this research, both primary and secondary, were obtained from interviews with resource persons, site observation, and tracing of supporting documents.

The data collecting technique in this research using Observation method, that is observation and recording with systematic phenomenon of investigated or under investigation. ${ }^{8}$ Interview Method, which is Data collection with unilateral questionnaire which is done systematically based on the purpose of investigation. ${ }^{9}$ Documentation method which is looking for data about things or variables in the form of notes, transcripts, books, newspapers, magazines, inscriptions, meeting minutes, ledger, agenda and so on.

\section{Results and Discussion}

\footnotetext{
${ }^{6}$ Jumadi Suryabrata, Metodologi Penelitian, (Jakarta : Raja Grafindo Persada, 1998), 84.

${ }^{7}$ Ibid, 85.

${ }^{8}$ Sutrisno, Hadi, Metode Research II, (Yogyakarta : Fakultas Psikologi UGM, 1987), 136.

${ }^{9}$ Sutrisno, Hadi, Metode Research II, (Yogyakarta : Fakultas Psikologi UGM, 1987), 136.
} 


\section{Definition of School Based Management (SBM)}

SBM is a word equivalent of School Based Management (SBM). In this case the World Bank has provided the notion that School Based Management (SBM) is a decentralized level of school administration authority to the school level. Responsibility and decision-making on implementation or the organization of the school has been submitted to the principal, teachers, parents, sometimes students or students, and members of other school communities.

On other occasions the World Bank also gives a slightly different meaning. SBM (School Based Management) is a strategy to improve schools by passing significant decision-making authority from the State and districts to individual school units. $^{10}$

School-Based Management can be defined as a management model that gives autonomy (greater authority and responsibility to the principal), provides flexibility to the principal, encourages direct participation of school members (teachers, students, principals, employees) and communities (parents, community leaders, scientists, employers) and improving the quality of schools based on national education policy and applicable laws and regulations. With such autonomy, schools are given the authority and responsibility to make decisions in accordance with the needs, capacities and demands of schools and existing communities. ${ }^{11}$

\footnotetext{
${ }^{10}$ Suparlan, Manajemen Berbasis Sekolah dari Teori Sampai dengan Praktik ( Jakarta : Bumi Aksara, 2013), 49.

${ }^{11}$ Rohiat, Manajemen Sekolah (Bandung : PT. Refika Aditama, 2012),47.
}

Based on this understanding, the implementation of SBM in school education unit is actually related to how the process of determining school policy should be determined by the school. With the SBM concept, the process of determining the policy should be established by all education stakeholders in the school. This is what is known as the main indicator or characteristic of SBM. If beforehand, the principal determines all school policies, then by SBM the principal should apply participative leadership, i.e. leadership with the principle of providing broad engagement to all stakeholders related to the provision of education in schools. Consequently, the success or failure from the implementation of such a policy will be a success or failure together. ${ }^{12}$

Birth of SBM initially used several different names, school-based governance, school self-management, and even school-based management. These terms do have a slightly different emphasis on understanding. However, these names have the same spirit, i.e. the school is expected to become more autonomous in the implementation of school management, especially in the use of its 3M, Man, Money, and Material. Autonomous handover in the management of school is given to improve the quality of education. Therefore, the Directorate of Junior High School named SBM as a Management of School-Based Quality Improvement. ${ }^{13}$

School Based Management (SBM) aims to improve school performance through the granting of

\footnotetext{
12 Suparlan, Manajemen Berbasis Sekolah dari Teori Sampai dengan Praktik ( Jakarta : Bumi Aksara, 2013),50.

${ }^{13}$ Suparlan, Manajemen Berbasis Sekolah dari Teori Sampai dengan Praktik ( Jakarta : Bumi Aksara, 2013),52.
} 
greater authority and responsibility to schools implemented on the principles of good school governance, namely participation, transparency and accountability. School performance includes improving the quality, effectiveness, efficiency, productivity, and education innovation.

With SBM, schools can improve their ability to plan, manage, finance, and organize education at their schools. With SBM, schools can also utilize and empower the available resources and can take care of the concerns of school residents and citizens in the organization of education in accordance with the ability possessed. reasons: ${ }^{14}$

MBS is applied for the following

a. With the provision of greater autonomy to schools, they will be more initiative and creative in improving school quality.

b. By providing greater flexibility to schools to manage their resources, they will be more flexible and lively in organizing and utilizing school resources optimally to improve school quality.

c. Schools are more aware of their strengths, weaknesses, opportunities, and threats so that they can optimize the use of available resources to advance their schools.

d. Schools are more aware of their needs, especially educational inputs that will be developed and utilized in the educational process in accordance with the level of development and needs of learners.

e. Decision making by schools is more suited to meet the needs of schools because it is the schools that know best what is best for them.

\footnotetext{
${ }^{14}$ Rohiat, Manajemen Sekolah (Bandung : PT. Refika Aditama, 2012),51.
}

$\mathrm{f}$. The use of educational resources is more efficient and effective if it is controlled by local communities.

g. The involvement of all school and community residents in school decision-making creates school transparency and accountability.

h. Schools can be responsible for the quality of their respective education to the government, parents of learners, and the community so that they will do their best to implement and achieve the planned quality of educational quality.

i. Schools can conduct fair competition with other schools in improving the quality of education through innovative efforts supported by parents, local communities, and local government, and

j. Schools can respond quickly to the aspirations of society and the rapidly changing environment.

School Based Management has characteristics that need to be understood by schools that will apply them. In other words, if the school wants to succeed in applying SBM, it characteristics need to be owned. Characteristics of SBM cannot be separated by effective school characteristics. If SBM is a container/framework, an effective school is its content. Therefore, SBM characteristics include the inclusiveness of effective school elements categorized into inputs, processes, and outputs. ${ }^{15}$

a. Expected output

School has expected output. School's output is a school achievement generated through learning and management processes in schools. In general output can be classified into two, namely the output of academic achievement and output in

${ }^{15} \mathrm{Ibid}, 57$. 
the form of non-academic achievement. Outputs of academic achievement are Value of National Final Examination/Value of National Examination, teen scientific contest, competition (English, Mathematics, Physics), way of thinking (Critical, creative diverging, reasoning, rational, inductive, deductive and scientific). Non-academic output, such as morals, and good social behavior such as drugfree, honesty, good cooperation, high affection towards others, high solidarity, tolerance, discipline, craft, sporting achievements, arts, and scouting.

\section{b. Process}

Effective schools generally have a number of process characteristics as follows:

1). Teaching and learning process with high effectiveness

2). Strong school leadership

3). Safe and orderly school environment

4). Effective management of teaching staff

5). School has a quality culture

6). School has a teamwork that is compact, intelligent, and dynamic

7). School has authority

8). High participation from school and community residents

9). School has management transparency

10). School has the will to change (Psychological and physical)

11). School conducts continuous evaluation and improvement

12). School is responsive and anticipatory to needs

13). Have good communication

14). School has accountability

15). Good school environmental management

16). School has the ability to maintain sustainability

c. Education Input
1). Have clear policies, objectives, and quality objectives

$2)$. Resources are available and ready

3). Competent and dedicated staff

4). Have high achievement expectation

5). Focus on customers (especially students)

6). Input management

According to the Association of American School Administrators (AASA), National Association of Elementary School Principals (NAESP), National Association of Secondary School Principals (NASSP) and other sources, stated that the benefits of SBM are:

a. Make competent individuals in the school to make decisions that can improve learning.

1) Giving voice to the entire school community in key decision-making. 2) Emphasizes accountability for decision making.

3) Encourage greater creativity in program design.

e. Redirecting resources to support the achievement of goals that have been developed in each school.

f. Encourage a realistic budget so that parents and teachers become more aware of the school's financial status, limited expenditures, and the costs required for program implementation, and

g. Increase the morale of teachers and other officers at all levels at school.

To implement the implementation of School Based Management (SBM) effectively and efficiently it must be supported by professional human resources. In this case the principal as the party has authority in empowering all existing resources should have knowledge of leadership, planning and a broad view of school and education. The authority of the principal must be grown by increasing the attitude of caring, the 
spirit of learning, the discipline of work, exemplary and human relations as the capital of the realization of conducive working climate.

Important things in the implementation of School Based Management (SBM) are the management of the components of the school itself. There are at least seven school components that must be managed in the context of SBM implementation:

a. Management of curriculum and teaching programs

b. Management personnel

c. Students' management

d. Financial management

e. Management of education facilities and infrastructure

f. Management of school and community relationships

g. Specialized service management

\section{Understanding the Quality of Education}

The quality of education consists of the word quality and education. Quality in Arabic is Hasuna means good. ${ }^{16}$ In English is quality, ${ }^{17}$ and in a large dictionary of Indonesian quality is size, good and bad thing; level or degree (intelligence, intelligence, etc.). ${ }^{18}$ In term of quality is quality meet or exceed customer's expectation. ${ }^{19}$ Thus the quality is the level of quality that has met or even exceeds than expected. According to Imam Al-Ghazali Education is a Wasilah to achieve the glory and surrender the soul to get closer to God. 20

\footnotetext{
${ }^{16}$ Mahmud Yunus, Kamus Arab Indonesia (Jakarta : Al-Ma'arif, 1984), 110.

17 John M. Echolis, Hasan Shadily, Kamus Inggris Indonesia (Jakarta : Gramedia, 1988), 460.

${ }^{18}$ Lukman Ali, Kamus Besar Bahasa Indonesia (Jakarta : Balai Pustaka, 1995), 677.
}

Based on some opinions can be concluded the quality of education is the quality or size of good or bad process of changing the attitude and behavior of a person or group of people in an effort to mature humans to get closer to God through the efforts of teaching and training guidance. Quality in the field of education includes the quality of input, process, output, and outcome. Educational input is considered qualified if ready to proceed. Education process is qualified if able to create an active, creative, and fun learning atmosphere (PAKEM).

There are several principles that need to be held in applying the quality of education programs are as follows:

a. Improving the quality of education demands professional leadership in education. Management of education quality is a tool that can be used by educational professionals in improving our nation's education system.

b. The difficulties faced by educational professionals are their inability to deal with "system failures" that prevent them from developing or implementing new ways or processes to improve the quality of education.

c. Improving the quality of education should make the leap of norms and old beliefs should be changed. Schools must learn to cooperate with limited resources. Educational professionals must assist students in developing the capabilities needed to compete in the global world.

\footnotetext{
${ }^{19}$ M.N Nasution, Manajemen Mutu Pendidikan

(Jakarta : Ghalia Indonesia,2004), 15.

${ }^{20}$ Muhammad Utsman al-Muhammady, Pemurnian Tasawuf oleh Imam Al-Ghazali, www/Scribd/com/doc/2917072/ tgl 19 November 2014.
} 
d. Money is not the key to improve quality. The quality of education can be improved if the administrators, teachers, staff, supervisors and heads of the national office develop a centralized attitude toward leadership, teamwork, cooperation, accountability, and recognition. Money is not a determinant in quality improvement.

e. The key to improving the quality of education is a commitment to change. If all teachers and school staff are committed to change, leaders can easily encourage them to find new ways to improve the efficiency, productivity, and quality of education services. Teachers will use a new approach or models of teaching, guiding, and training in fostering student growth. Similarly, administrative staff, he will use new processes in costing, solving problems, and developing new programs.

f. Many educational professionals lack the knowledge and expertise in preparing students to enter the global job market. Fear of change or fear to do the change will lead to ignorance of how to cope with new demands.

g. Commercial quality improvement programs cannot be used directly in education, but require adjustments and improvements. The culture, environment, and work processes of each organization are different. Educational professionals should be provided with programs specifically designed to support education.

h. One of the key components in the quality program is the measurement system. Using a measurement system enables educational

${ }^{21}$ Nana Syaodih Sukmadinata, Dkk, Pengendalian Mutu Pendidikan Sekolah professionals to demonstrate and document the added value of implementing quality improvement programs for students, parents and the community.

i. Society and management of education should abstain from the habit of using "short program", quality improvement can be achieved through continuous change not with short programs. ${ }^{21}$

The transformation toward a quality school begins by adopting a shared dedication to quality by school boards, administrators, staff, students, teachers and the community. The process begins with developing the vision and mission of quality for territories, every school and department within the region. ${ }^{22}$ The vision of quality is focused on five things, namely:

a. Fulfill the needs of customers

In a quality school, everyone becomes a customer and as a supplier all at once. In particular, school customers are students and their families, who will benefit from the results of an educational institution/school. While in the general assessment of the school customer there are two, namely internal which include parents, students, teachers, administrators, staff and school boards that are in the education systems. External customers are communities, companies, families, military, and colleges that are outside the organization but utilize the output of the educational process.

b. Total community involvement in the program

Everyone should also be involved and participate in order

Menengah: Konsep, Prinsip, dan Instrumen (Bandung: Refika Aditama, 2006), 9-11.

22 Ibid, 10. 
towards the transformation of quality. Quality is the responsibility of all parties.

c. Measurement of value added education

This measurement is precisely what often fails at school. Traditionally the quality measure of a school's family is a student's achievement, and its basic measure is a test. When test results improve, the quality of education improves.

d. View education as a system

Education should be viewed as a system. This is a very difficult concept to understand by educational professionals. For example, people working in education and start to improve the system without developing a full understanding of how the system works. Just by looking at education as a system then educational professors can eliminate waste of education and can improve the quality of every educational process.

e. Continuous improvement by always striving to make educational output better

Quality is anything that can be improved according to the old management philosophy of "if it has not been broken do not repaired", the quality is based on the concept that every process can be improved and there is no perfect process. According to the new management philosophy "if it is not damaged, correct it, because if it is not done by you, then others will do", this is the concept of continuous improvement. ${ }^{23}$

There are several factors that influence in improving the quality of education, namely:

a. Teacher

23 Ibid, 11-14.
In the process of teaching and learning, teachers play an important role in the purpose of education as well as director and actor, meaning that the success of teaching and learning process lies on the teacher for that teacher is a very dominant factor in determining the success of teaching and learning process. ${ }^{24}$

To achieve success, teachers must be able to plan the teaching and learning program effectively and have sufficient knowledge about the principles of learning as the basis for designing the teaching and learning program, such as formulating objectives, selecting materials, selecting methods, establishing evaluations and so forth. Therefore, teachers are required to have the competence in order to bring their students to the goals they want to achieve.

b. Student

Students are those who become the main object in teaching and learning process. Students are a place of bed the seeds of science and experience developed by the teacher. The bed has a basic ability (talent), maturity, unequal intelligence in its development. Therefore, in order to bring the quality of good education closer, it is necessary to prepare the students in order to receive or transfer the knowledge or experience of the teacher which is done automatically, planned or continuous from one level to another. The better the preparation is given to the students then the better the quality and ability of students to receive education.

In addition to the basic skills possessed by students, there are also other factors that need to be

\footnotetext{
${ }^{24}$ Cece Wijaya, Tabrani Rusyan, Kemampuan Dasar Guru dalam Belajar Mengajar, ( Bandung : Rosda Karya, 1991), 13.
} 
considered such as learning motivation, learning, interest, attention, persistence attitude, social, economic, physical and psychological factors. Because the quality of education to be considered is the facet of students, because students are objects that must be directed.

c. Curriculum

The curriculum in the broadest sense is the whole program and school life. Therefore, the curriculum is very influential on the advancement of education. In this case things to be noted are the problem of components contained in the curriculum, where one affect each other:

1) Institutional objectives

2) Structure of the curriculum program

3) Outline of the teaching program

4) The teaching system

5) Assessment system

6) Supervise and administration

With regard to the curriculum component, the quality of education will be expected. Similarly, education will be of low quality if the curriculum is not considered.

d. Method

Besides having to master the material to be delivered, the teacher must also master the methods of learning. The role of method is very important in teaching and learning process to achieve the purpose of teaching, without proper method of teaching purpose cannot be achieved optimally. Therefore, teachers should be able to master and choose the method that is commonly used with the following criteria:

1) The method must be in accordance with the purpose of teaching

2) The method should be in accordance with the time, place and tools available and in accordance with the teacher's duties

3) The method should be appropriate to the type of activities covered in the lesson

4) Methods should be appropriate to the type of student's interest and attention

5) The method must be appropriate in its use as well as its purpose should be understood by the student.

By considering these criteria, the objectives and improvement of education, quality will be achieved optimally in accordance with national education objectives.

e. Facilities and infrastructure

Infrastructure in teaching and learning process is needed in order to achieve the purpose of teaching.

The facilities needed in improving the quality of education are textbooks for teachers and students, drawings, libraries, practice rooms and so forth.

\section{f. Supervision}

To improve the quality of education required supervision. Who carries out the task is the supervisor, in this case the principal. Supervisors must implement several supervision techniques in performing their duties. g. Parents

In relation to improve the quality of education, the role of parents is very supportive. Besides they become a supervisors of the learning activities of children they also as mentors of children.

With regard to the foregoing, it is clear that the criteria for quality education are:

1) A teacher should be able to protect his or her students, both within the school environment and outside the school environment 
2) Students should be able to learn well what has been given by the teacher

3) The curriculum must be in accordance with the national situation and condition

4) The method used should be in accordance with the material and ability of the students

5) Facilities and infrastructure of mutual support

6) Parents should always encourage and encourage children's activities.

\section{School Based Management (SBM) in KHM. NUR Junior High School Surabaya}

School that has implemented

School Based Management (SBM) almost every year has always an increase, both in the field of academic and non-academic. Implementation of School Based Management (SBM) has a great impact in developing the potential of learners because schools can freely determine the appropriate programs with the conditions of students in KHM. NUR Junior High School Surabaya.

In the academic field, the school schedules examination preparations for class IX starting from October in the first semester, such as try out, additional lessons, and spiritual debriefing. Whereas, in non-academic field the school adds extracurricular activities significantly to follow the potential of students in KHM. NUR Junior High School and won numerous awards in non-academic championships.

KHM. NUR Junior High School Surabaya is also active in maintaining harmonious relationships with guardians, surrounding communities, and alumni. The socialization program at the beginning of the school year for new students is very helpful for the smoothness of activities programs in KHM. NUR Junior High School Surabaya. Likewise with the alumni who have the potential to transmit their abilities by helping their younger siblings in KHM. NUR Junior High School Surabaya became a supervisor in the field which they supported.

Programs implemented by KHM. NUR Junior High School Surabaya as a form of application of School Based Management (SBM) in the academic field, among others; Preparation for the final exam for class IX has been implemented since October semester I in each academic year. Schools have provided additional learning and cooperate with various educational institutions either independently or follow the Ma'arif program. To get maximum results, the school specializes 30 students who have above average skills to gain additional extra learning from the experts in the field of study who are in the final exam. From the 30 students above, it will be taken 5 best students to be included in the try out program and extra learning from $M a^{\prime}$ arif institutions. While in the field of non-academic, among others; The school has an extracurricular program that can foster the potential of students, such as scouts, self-defense, samroh, hadrah, and inheritance flag bearers troop. For the scouts, KHM NUR Junior High School Surabaya once won the Ma'arif level. Samroh extracurricular also won the first place among junior high schools at the subdistrict level. While the self-defense extracurricular, KHM NUR Junior High School Surabaya got the most awards, both for the category of competition and arts, among others Champion I, II, III and good expectancy for both sons and daughters in the championship held by KONI in Surabaya city. For inheritance flag 
bearers troop extracurricular KHM NUR Junior High School Surabaya cooperates with KAL Vocational High School. The alumni who continue their education at KAL Vocational High School provides marching and discipline lines to their younger siblings at KHM NUR Junior High School Surabaya. In addition to academic and non-academic fields, KHM NUR Junior high School Surabaya also has programs related to the community and parents, among others; Student socialization for each year of lessons to discuss school policies and programs within 3 years, parenting activities for guardians of class IX, and cross-sector meetings to maintain harmonization at KHM NUR Junior high School Surabaya.

\section{Conclusions}

After studying, researching, understanding, and analyzing the application of School Based Management (SBM) to improve the quality of education in KHM. NUR Junior High School Surabaya, it can be concluded that: Schools that have implemented School Based Management (SBM) almost every year has always an increase, both in the field of academic and non-academic. In implementing School Based Management (SBM), KHM NUR Junior High School Surabaya found supporting factors namely; The existence of funds from the government in the form of BOSNAS (National School Operational Assistance) and BOPDA (Province Education Operational Assistance) allocated to realize the school programs to improve the quality of education in KHM. NUR Junior High School Surabaya, the addition of donation funds from the guardian of students who can help to realize the school's programs to improve the quality of education in KHM. NUR Junior high School Surabaya, and the enthusiasm of the school residents in KHM NUR Junior high School Surabaya to realize the school's programs. While the inhibiting factors are; Funds from the government in the form of BOSNAS (National School Operational Assistance) and BOPDA (Province Education Operational Assistance) often experience delays in disbursement, while KHM NUR Junior High School Surabaya programs had to walk, low understanding of the guardian of student to pay donation fund make not all guardian give it due to economic level of KHM NUR Junior high School Surabaya guardian is middle to low, and not all of school residents have awareness to participate in realizing school programs in improving the quality of education in KHM NUR Junior High School Surabaya. The environment of the lowly educated majority of the community views the school only to obtain a copy of a Junior High School diploma without the need for other programs.

\section{E. References}

Cece Wijaya, Tabrani Rusyan. Kemampuan Dasar Guru dalam Belajar Mengajar. Bandung: Rosda Karya. 1991.

Usman, Husaini, et.al. Metodologi Penelitian sosial . Jakarta: PT. Bumi Aksara. 2006.

Pande, Irmansyah Ali. Didaktik Metodik Pendidikan Umum. Surabaya: Usaha Nasional. 1984.

Echolis, John M, Hasan Shadily. Kamus Inggris Indonesia. Jakarta: Gramedia. 1988. 
Suryabrata, Jumadi. Metodologi Penelitian. Jakarta: Raja Grafindo Persada. 1998.

Moloeng, Lexy J. Metode Penelitian Kualitatif. Bandung: PT. Remaja Rosdakarya. 2002.

Ali, Lukman. Kamus Besar Bahasa Indonesia. Jakarta: Balai Pustaka. 1995.

Nasution, M.N. Manajemen Mutu Pendidikan. Jakarta: Ghalia Indonesia. 2004.

Yunus, Mahmud. Kamus Arab Indonesia. Jakarta: Al-Ma'arif. 1984.

Muhaimin. Pengembangan Kurikukum PAI di Sekolah dan Perguruan Tinggi. Jakarta: PT Raja Grafindo Persada. 2005.

Muhammad Utsman al-Muhammady. Pemurnian Tasawuf oleh Imam Al-Ghazali.
www/Scribd/com/doc/2917072

/ 19 November 2014.

Sukmadinata, Nana Syaodih, et.al. Pengendalian Mutu Pendidikan Sekolah Menengah: Konsep, Prinsip, dan Instrumen. Bandung: Refika Aditama. 2006.

Rohiat. Manajemen Sekolah. Bandung: PT. Refika Aditama. 2012.

Standar Nasional Pendidikan (SNP) dan Undang-undang RI No. 20 tentang Sistem Pendidikan Nasional. Bandung: Fokusmedia. 2005.

Suparlan. Manajemen Berbasis Sekolah dari Teori Sampai dengan Praktik. Jakarta: Bumi Aksara. 2013.

Hadi, Sutrisno. Metode Research II. Yogyakarta: Fakultas Psikologi UGM. 1987. 